\title{
A Good try to Build a Scientific Psychology
}

\author{
Ziqian Wu* \\ Shenzhen Institute, China \\ Submission: April 04, 2018; Published: April 10, 2018 \\ *Corresponding author: Ziqian Wu, Shenzhen Institute, China; Email: woodschain@sohu.com
}

\section{Short Communication}

There are so many psychologies, such as structuralism of Wilhelm Wundt (1832 1920), functionalism of William James (1842 1910) and John Dewey (1859 1952), behaviorism of John B. Watson (1878 1958), gestalt psychology of Max Wertheimer (1880 1943), psychoanalysis of Sigmund Freud (1856 1939), humanistic psychology of Abraham Maslow (1908 1970) and Carl Rogers (1902 1987), cognitive psychology and neuropsychology. More and more psychologies are being created or will being created. Now days there are hundreds of thousands of psychologists. Do they accept such a confused situation? May be you are a new comer in this field, you say" what a strange subject, it seems not like science". I suggest you read the paper "Core Equations for Psychology"; it can dissolve the doubts in your mind. May be you are a psychologist having several years experience in the subject but you want to say good bye to it. You will change your mind after reading the paper. Psychology is not so annoying, it doesn't make you despair. May be you are a psychologist being in the end of your academic career, I ask you read the paper, it should supply you the answer about the doubt filled in your academic career.

There are a few of psychologists who believe that one can find a uniform theory of psychology. If you are one of them please read the paper. Is the theory mentioned in the paper a perfect one you expected? There are so many psychologies who do not believe there is a uniform theory of psychology. If you are one of them please read the paper. May be you will change your thoughts. "Oh, it is possible to create a scientific theory about our subject". The paper "Core Equations for Psychology" introduced a set of new scientific concepts, such as mental representation, mental operation and mental force, to describe status of human mental behavior. It built relationships between mental operation and mental force and takes them as core equations for psychology to show reason about mental status. It is the first time in human history to give a set of scientific concepts and core equations for psychology.

This paper gives also a new principle of automatically saving so it is also suited to the readers from the field of artificial intelligence. The paper gave the most key point to build a uniform psychology. Find out the only quite right basic relation! First, the basic relation is steady and any other ones will never be steady. For example, we ask Mr. Bill: 'what is your name?' he answered' My name is bill'. If we ask him secondly, he may be confused. We ask him again, he may get angry and refuse to answer us. Surely we will never build a steady relation between our questions and Mr. Bill's answers. But many psychologists, specially, behaviorists made mistakes like this. They know they do not go upon a right direction but they do not know where the right direction is.

Solving other problems before building the basic relation will make things difficult. We know net force then we know acceleration. It will become a multi-body problem if the force is unknown. Ask professors of mechanics and discuss with them, recall what you learned in the text book in middle school. Is the opinion mentioned here right? Many psychologists tried to solve problems like multi-body problems before their building the basic relation of their subject!

Some psychologists made other type of mistakes. They try to explain thinking logically. Unluckily not each thinking obey logic. They tried to interpret behavior by rules. Unluckily not each behavior obeys regulars. Logic influences thinking in some period of time and in some degree. Regular can restrict action but never decide it entirely. They failed when thinking doesn't obey logics or behavior doesn't obey regular. A really theory of psychology will contain all phenomena of thinking and of behaviors. One knows this point deeply but they cannot do anything to improve it. They cannot explain the unlogical thinking's that happened frequently in daily life. They made the third type of mistakes. They mix up human thinking and the theory about human thinking. Human thinking may be unlogical or disordered but the theory about human thinking should be rigorous and logical and uniform.

A real scientific theory of psychology should logically answer the questions of 'what is it' and 'why is it so 'about human thinking and human behaviors. Newton's classic mechanics is a 
brilliant example. Its predictions are true. That is say the theory can be validated by tests. It attributes all macroscopic motion phenomena to a set of equations thus it makes the logic of the things so simple and non-contradictory. That is say the theory can be validated by logics. The author's major is mechanics so he understands deeply the spirit of science. One may ask why did a author learning mechanics give such a theory about psychology? I want to ask 'who is suit to do so, a mechanics or a psychologist? My answer is 'a mechanics!' Why? Psychologists accept the current situation of the subject, where is the power for them to create a uniform theory? But for mechanics, they have the motivation to do that thing. In their opinion current psychologies are not science and they cannot accept any of these psychologies.
There are so many test results for psychologies but there is not a set of scientific concepts and core equations that can rules all these results. I think it is a right thing for psychologists to drop everything they are doing and think about the direction of the subject. Please read the paper "Core Equations for Psychology", think about the direction of the subject again! If they did not do so, new comer of them will be confused in their entire academic career and ones saying good bye to psychology will be despair when they enter other subjects. Few, very few subjects are as perfect as Newton's classic mechanics. Read the paper "Core Equations for Psychology", think about the direction of psychology, please!

\section{Your next submission with Juniper Publishers will reach you the below assets}

- Quality Editorial service

- Swift Peer Review

- Reprints availability

- E-prints Service

- Manuscript Podcast for convenient understanding

- Global attainment for your research

- Manuscript accessibility in different formats

( Pdf, E-pub, Full Text, Audio)

- Unceasing customer service

Track the below URL for one-step submission https://juniperpublishers.com/online-submission.php 